Przegląd Prawa Konstytucyjnego - -ISSN 2082-1212--------

DOI 10.15804/ppk.2016.02.14

-Nr $2(30) / 2016-------$

Jakub Grzegorz Firlus $^{1} \quad$ Natalie Fox $^{2}$

\title{
Glosa do postanowienia Naczelnego Sądu Administracyjnego z dnia 16 października 2015 r., I OSK 1992/14³
}

I.

Jednym z zasadniczych mankamentów polskiego modelu dwuinstancyjnego postępowania sądowoadministracyjnego jest brak - w płaszczyźnie normatywnej - dostatecznych instrumentów zabezpieczających w pełni realizację standardu szybkości i efektywności postępowania ${ }^{4}$. Stąd też podejmowane są próby dekodowania właściwego standardu dostępu do sądu. W sferze wykładniczej orzecznictwo sądów administracyjnych w sposób twórczy limituje dostęp tak do wojewódzkiego sądu administracyjnego, jak również do Naczelnego Sądu Administracyjnego próbując wyważać wartości pozostające w konflikcie. Przy czym analiza rozstrzygnięć podejmowanych przez

Autor jest doktorantem w Katedrze Postępowania Administracyjnego Wydziału Prawa i Administracji Uniwersytetu Jagiellońskiego w Krakowie. E-mail: firlus.jakub@gmail.com.

2 Autorka jest doktorantką w Katedrze Prawa Ustrojowego Porównawczego Wydziału Prawa i Administracji Uniwersytetu Jagiellońskiego w Krakowie. E-mail: foxnataliemail@ gmail.com.

3 LEX nr 1975884; dalej cyt., jako „postanowienie NSA z 16 października 2015 r.”.

4 Z. Kmieciak, Efektywność sądowej kontroli administracji publicznej, „Państwo i Prawo” 2010, z. 11; B. Banaszak, K. Wygoda, Funkcjonowanie sądownictwa administracyjnego w Polsce w zderzeniu z problemami współczesności, „Studia Iuridica Lublinesia” 2014, nr 22, s. 172 i n. 
sądy uzasadniania twierdzenie o istnieniu dwóch przeciwstawnych tendencji. Z jednej strony, ochrona prawna udzielana skarżącym przez sądy administracyjne uchodzi za przenoszącą standard wymagany przepisami ustawy zasadniczej ${ }^{5}$. Nazbyt szeroki dostęp do sądownictwa administracyjnego implikuje w sferze faktualnej globalną przewlekłość postępowań. Z drugiej strony, wgląd na postulat realizacji funkcji sądowej kontroli działalności administracji publicznej w rozsądnym terminie implikuje niejednokrotnie nadto formalistyczne, a jednocześnie ograniczające podstawowe prawa jednostek rozstrzygnięcia sądów administracyjnych wyznaczających dostęp do sądu ${ }^{6}$. Również podejmowane przez ustawodawcę próby usprawnienia postępowania sądowoadministracyjnego budzą uzasadnione wątpliwości z punktu widzenia konstytucyjnego prawa do sądu czy standardu dwuinstancyjności postępowania.

W związku z powyższym nadal aktualne pozostaje pytanie o optymalny zakres dostępu do sądu administracyjnego. Interesujący głos w owej dyskusji stanowi wzmiankowane w tytule niniejszego opracowania orzeczenie. Skład sędziowski NSA powziął wątpliwość czy wszystkie skargi w sprawach, które prima facie należą do właściwości sądów administracyjnych powinny podlegać merytorycznemu rozpoznaniu przez sąd. Wątpliwości NSA powodowane były celowością udzielania ochrony prawnej skarżącym nadużywającym prawa do sądu. W ocenie składu pytającego skargi w sprawach oczywiście i rażąco błahych winny podlegać odrzuceniu a limine. Przy czym, podstawę prawną owego rozstrzygnięcia sądu miałyby stanowić stosowane bezpośrednio przepisy konstytucji.

5 Wyrok NSA z 9 października 2013 r., II FSK 2497/13, LEX nr 1441258, gdzie sąd dokonując wykładni sprzecznej z wyraźnym brzmieniem przepisów procesowych przesądził dopuszczalność drogi sądowej w sprawie, w której należało odmówić ochrony prawnej skarżącemu.

6 Egzemplifikację takiego nazbyt formalistycznego sposobu wykładni przepisów ustawy procesowej stanowi linia orzecznicza wsparta wypowiedziami doktryny w zakresie wymogów konstrukcyjnych skargi kasacyjnej. Na temat wymogów konstrukcyjnych skargi kasacyjnej, zob. H. Knysiak-Molczyk, Skarga kasacyjna w postępowaniu sądowoadministracyjnym, Warszawa 2010, s. 139-141. Dopiero wyrok TK ustalił właściwy sposób postępowania sądów w sytuacji zaistnienia braku formalnego środka zaskarżenia; zob. wyrok Trybunału Konstytucyjnego z 8 kwietnia 2014 r., SK 22/11. 
II.

Kontrola działalności administracji publicznej sprawowana przez sądy administracyjne ma charakter ograniczony ${ }^{7}$. Okoliczność ta aktualizuje się w dwóch momentach. Po pierwsze, zakres rzeczowy sądownictwa administracyjnego jest limitowany przez ustawodawcę ${ }^{8}$, który to na zasadzie klauzuli generalnej ${ }^{9}$ wskazuje jakie prawne formy działalności administracji publicznej podlegają kontroli przez sądy administracyjne ${ }^{10}$. Po drugie, ograniczony charakter kontroli wynika z przepisów procesowych konstruujących przede wszystkim płaszczyznę dopuszczalności drogi sądowej. Stanowi ona zbiorczą kategorię wymogów (kryteriów), od spełnienia których uzależniona jest skuteczność skargi ${ }^{11}$. Przy uwzględnieniu okoliczności jaką jest konsekwentna realizacja w postepowaniu sądowoadministracyjnym zasady skargowości ${ }^{12}$ można skonstatować, iż jedynie dopuszczalna, ergo skuteczna skarga inicjuje działalność kontrolną sądu administracyjnego. Aktywność jednostki jedynie imitująca skargę bądź też czynność zaskarżenia niedopuszczalna w płaszczyźnie procesowej, doprowadzi do zainicjowania wyłącznie stadium wstępnego ${ }^{13}$ postępowania przez sądem administracyjnym.

Podstawowe znaczenie dla oceny dopuszczalności skargi ma treść art. 58 ustawy z 30 sierpnia 2002 r. - Prawo o postępowaniu przed sądami admini-

7 T. Woś, [w:] H. Knysiak-Molczyk, M. Romańska, Prawo o postępowaniu przed sądami administracyjnymi. Komentarz, red. T. Woś, Warszawa 2012, s. 22-23.

8 Art. 184 Konstytucji RP.

9 T. Woś, [w:] Prawo o postępowaniu..., s. 50-51.

10 J.P. Tarno, Prawo o postępowaniu przed sądami administracyjnymi. Komentarz, Warszawa 2012, s. 24-25. Generalnie wskazuje się, iż zakres działania sądów administracyjnych (właściwość rzeczową) wyznaczają dwa kryteria. Po pierwsze, prawna forma działania administracji publicznej, a po drugie, przynależność owej formy do kategorii czynności z zakresu administracji publicznej.

11 M. Bogusz, Zaskarżenie decyzji administracyjnej do Naczelnego Sądu Administracyjnego, Warszawa 1997, s. 68.

12 T. Woś, Związki postępowania administracyjnego i sądowo-administracyjnego, Warszawa-Kraków 1989, s. 18.

13 W literaturze wyróżnia się trzy stadia postępowania sądowoadministracyjnego. Zob. W. Chróścielewski, Wszczęcie postępowania sądowoadministracyjnego, „Państwo i Prawo” 2004, z. 3, s. 70 . 
stracyjnymi ${ }^{14}$. Przepis ten zawiera katalog przesłanek warunkujących możliwość merytorycznego rozpoznania sprawy przez sąd. Przy czym podkreślenia wymaga fakt, iż owo wyliczenie ma jedynie względnie wyczerpujący charakter. Ustawodawca wprawdzie w art. $58 \$ 1$ pkt $1-5$ p.s.a. wskazuje explicite okoliczności, których zaistnienie czyni dalsze postępowanie niedopuszczalnym niemniej jednak istnieje dodatkowa, zbiorcza kategoria „,innych przyczyn” skutkujących odrzuceniem skargi ${ }^{15}$. W kontekście komentowanego orzeczenia istotne znaczenie ma przesądzenie źródła, z którego należy dekodować treść innych niźli wymienione w art. $58 \$ 1$ pkt 1-5 p.s.a. okoliczności warunkujących skuteczność czynności zaskarżenia. Słusznie wskazuje się, że analiza treści poszczególnych przesłanek powinna być dokonywana przy uwzględnieniu obowiązujących przepisów procesowych ${ }^{16}$. W rezultacie okoliczności te można dekodować bądź to $z$ treści p.s.a. bądź też w przepisów szczególnych ${ }^{17}$. Choć niejednokrotnie dla właściwego ustalenia zakresu konkretnej przesłanki niedopuszczalności przydatne mogą być normy prawa konstytucyjnego ${ }^{18}$ to mają one jedynie wspomagać wykładnię przepisów ustawowych. Co istotne w literaturze zaleca się powściągliwość w zakresie kreowania nowych, nieznanych ustawie warunków, których niezaistnienie in concreto miałoby skutkować zamknięciem drogi sądowej ${ }^{19}$.

Istotnie analiza orzecznictwa sądów administracyjnych na gruncie art. 58 $\$ 1$ pkt 6 p.s.a. może uzasadniać twierdzenie o niezwykłej pojemności klauzuli „innych przyczyn” aktualizujących niedopuszczalność postępowania sądowoadministracyjnego ${ }^{20}$. Niemniej jednak konkretna przyczyna skutkująca odrzuceniem skargi stanowi rezultat wykładni przepisów procesowych (usta-

\footnotetext{
14 T.j. Dz.U., poz. 270 ze zm.; dalej jako: „p.s.a.”.

15 Art. $58 \$ 1$ pkt 6 p.s.a.

16 M. Bogusz, op.cit., s. 68.

17 T. Woś, [w:] Prawo o postępowaniu..., s. 460.

18 P. Razowski, Niedopuszczalność drogi sądowej w postępowaniu sądowoadministracyjnym, Warszawa 2015, s. 99.

19 K. Kaszubowski, Wymogi formalne skargi do wojewódzkiego sądu administracyjnego (wybrane zagadnienia), „Gdańskie Studia Prawnicze” 2012, T. XXVIII, s. 167.

$20 \mathrm{~W}$ orzecznictwie wskazuje się, że skarga podlega odrzuceniu np. w przypadku jej przedwczesności bądź też wniesienia przez nieistniejącą - na moment wnoszenia skargi spółkę; zob. postanowienie WSA z 11 marca 2015 r., II SAB/Łd 16/15, LEX nr 1768679; wyrok NSA z 10 grudnia 2014 r., I FSK 1809/13, LEX nr 1585922.
} 
wowych). Tym samym klauzula „innych przyczyn” de lege lata nie może stanowić samoistnej okoliczności uzasadniającej ograniczenie dostępu do sądu. Dlatego też zasadnie można twierdzić, że na gruncie okoliczności konkretnej sprawy sądowoadministracyjnej katalog przyczyn skutkujących niedopuszczalnością skargi ma sui generis charakter zamknięty. Sąd administracyjny jest zobowiązany do zastosowania przepisanego prawem rygoru procesowego jedynie wówczas, gdy na gruncie obowiązujących przepisów ustawowych można w sposób niebudzący wątpliwości ustalić - również w drodze wykładni - że dana okoliczność stanowi przesłankę dopuszczalności postępowania ${ }^{21}$.

\section{III.}

W świetle poczynionych powyżej uwag należy rozważyć prawidłowość rozwiązania sugerowanego przez sąd w pytaniu prawnym. NSA w komentowanym postanowieniu za dostateczną podstawę ustalenia pozaustawowej przesłanki dopuszczalności postępowania sądowoadministracyjnego uznał przepisy konstytucji. Jako właściwą postawę prawną odrzucenia skargi zaproponowano treść art. $58 \$ 1$ pkt 6 p.s.a. w zw. z art. 8, art. 2 oraz art. 45 ust. 1 Konstytucji RP. Przy czym przesłanka ograniczenia dostępu do sądu została ujęta w sposób opisowy w postaci wniesienia skargi „w sprawie oczywiście i rażąco błahej”. Ocena prawna przytoczonej konstrukcji wymaga wielopłaszczyznowej analizy. W szczególności zaś odwołania się do bogatego dorobku doktryny w zakresie bezpośredniego stosowania Konstytucji RP.

Jak się wydaje NSA w sposób prawidłowy dekodował znaczenie klauzuli „inny przyczyn”, jako przepisu odsyłającego poza treść art. $58 \$ 1$ p.s.a. Tym samym potwierdził niesamodzielny charakter omawianej przesłanki niedopuszczalności skargi. Przy czym, jako dostateczną podstawę prawną odrzucenia skargi uznane zostały przepisy Konstytucji RP. W uzasadnieniu pytania prawnego stwierdzono, bowiem, że ,jeżeli możliwe jest ustalenie na ich podstawie określonej normy prawnej" to wówczas przepisy ustawy zasadniczej mogą stanowić podstawę negatywnego rozstrzygnięcia sądu w zakre-

21 Przykładowo do takowych okoliczności można zaliczyć pisemne wezwanie organu do wykonania wyroku lub załatwienia sprawy, o który mowa w art. 154 \ 1 p.s.a.; zob. postanowienie NSA z 26 sierpnia 2014 r., I FSK 1114/14, LEX nr 1499796. 
sie oceny dopuszczalności drogi sądowej. Jak się wydaje podstawę prawną rozstrzygnięcia sądu w omawianym przypadku miały zasadniczo stanowić przepisy konstytucji ${ }^{22}$. W rezultacie należałoby przyjąć, iż sąd zmierzał do samoistnego zastosowania przepisów konstytucji ${ }^{23}$. Przy czym owo bezpośrednie oparcie rozstrzygnięcia sądu na przepisach ustawy zasadniczej jawi się, jako szczególnego rodzaju. Zważyć należy, iż podstawę prawną zastosowania rygoru procesowego $\mathrm{w}$ postaci odrzucenia skargi mają stanowić przepisy ustawy tj. art. $58 \$ 1$ pkt 6 p.s.a. Jedynie w zakresie niezbędnego elementu, jakim jest procesowa przyczyna niedopuszczalności drogi sądowej należałoby sięgnąć do norm konstytucyjnych. Tylko w tym wycinkowym zakresie, dekodowana na podstawie konstytucji norma prawna ma uzupełnić przepisy procesowe o dodatkową przesłankę dopuszczalności postępowania sądowoadministracyjnego. W związku z powyższym należy rozważyć czy zabieg ten jest prawidłowy. W piśmiennictwie można wskazać na poglądy wykluczające możliwość samoistnego stosowania konstytucji w przypadku, gdy przepis ustawy zasadniczej choćby częściowo odsyłał do regulacji ustawowej $^{24}$. Już tylko z uwzględnieniem tej przyczyny sąd nie jest uprawniony do konstruowania pozaustawowej przesłanki ograniczającej dostęp jednostki do sądu z odwołaniem się wyłącznie do przepisów ustawy zasadniczej. Odnotować należy, iż ustrojodawca pozostawia ustawodawcy autonomię (luz decyzyjny) w zakresie kreowania modelu postępowania sądowego ${ }^{25}$.

22 Sąd wskazuje, że „wszelako przepisy Konstytucji mogą stanowić podstawę orzekania w tych sytuacjach, w których brak jest, zawartych w ustawach zwykłych, uregulowań odnoszących się do pewnego stanu faktycznego".

23 L. Garlicki, Bezpośrednie stosowanie konstytucji. Wprowadzenie do dyskusji, [w:] Konferencja naukowa: Konstytucja RP w praktyce, Warszawa 1999, s. 23-24. Słusznie, bowiem autor wskazuje, że samoistne stosowanie konstytucji polega na oparciu rozstrzygnięcia organu stosującego prawo bądź to wyłącznie bądź w zasadniczym zakresie na przepisach konstytucji.

${ }^{24}$ K. Działocha, Bezpośrednie stosowanie Konstytucji RP (stan doktryny prawa), [w:] Bezpośrednie stosowanie Konstytucji Rzeczypospolitej Polskiej, red. K. Działocha, Warszawa 2005, s. 21. Przy czym jednocześnie należy podkreślić, iż pogląd ten jest jedynie częściowo aprobowany w doktrynie, na co zwraca uwagę autor.

25 L. Garlicki, Komentarz do art. 176, [w:] Konstytucja Rzeczpospolitej Polskiej. Komentarz, T. IV, red. L. Garlicki, Warszawa 2004, s. 10-11. Zob. również zakresie dopuszczalności wyboru przez ustawodawcę modelu środka prawnego inicjującego tok instancji B. Adamiak, Uwagi o modelu dwuinstancyjnego postępowania sadowoadministracyjnego, [w:] Procedura administracyjna wobec wyzwań współczesności, Łódź 2004, s. 29. 
Stąd też to ustawa ma określać przesłanki (przyczyny, powody) aktualizujące obowiązek sądu zastosowania rygoru przepisanego w art. $58 ₫ 1$ p.s.a. Ponadto należy wskazać, że jedną z przesłanek samoistnego stosowania konstytucji jest jednoznaczność i konkretność stosowanej normy konstytucyjnej $^{26}$. Nie sposób zatem zgodzić się z poglądami jakoby niejasność i wieloznaczność tekstu ustawy zasadniczej nie stanowiła negatywnej przesłanki stosowania art. 8 ust. 2 Konstytucji $\mathrm{RP}^{27}$. W literaturze zostało ponad wszelką wątpliwość wykazane - w szczególności na gruncie treści art. 45 ust. 1 Konstytucji RP - iż dowolne podejście do tzw. przesłanki jednoznaczności przepisu prowadzi do nieakceptowalnych systemowo rozwiązań ${ }^{28}$.

Jakkolwiek ustalona przez autorów - na podstawie okoliczności pytania prawnego - forma bezpośredniego stosowania konstytucji nie koresponduje z przyjętym przez NSA założeniem. Sąd bowiem uznał, że podjęty przezeń zabieg wykładniczy stanowi tzw. współstosowanie konstytucji ${ }^{29}$ (art. 2 oraz 45 ust. 1 Konstytucji) z przepisem procesowym (art. $58 \$ 1$ pkt 6 p.s.a.). Odnotować należy, iż współstosowanie tzw. interpretacyjne ma miejsce wówczas, gdy organ stosujący prawo dekodując normę prawną, stanowiącą podstawę podejmowanego rozstrzygnięcia bierze pod uwagę zarówno normę ustawową, ale również tę ustaloną w oparciu o przepisy konstytucji ${ }^{30}$. Wykładnia ustaw w zgodzie z konstytucją stanowi szczególną kompetencję przydaną systemowo przede wszystkim sądom. Wskazuje się wręcz „że sądownictwo jest pod tym względem niezastąpione" ${ }^{31}$. Co więcej obowiązek ${ }^{32}$ wykładni prokonstytucyj-

26 L. Garlicki, Bezpośrednie stosowanie..., s. 24; K. Działocha, Wewnętrzna hierarchia norm konstytucji w orzecznictwie Trybunału Konstytucyjnego, [w:] Państwo, ustrój, konstytucja: studia, red. Z. Mańkowski, Lublin 1991, s. 46; A. Kozak, Pojmowanie prawa w teorii wykładni, Wrocław 1997, s. 30 i n.

27 A. Kozak, Konstytucja jako podstawa stosowania prawa, [w: Z Zagadnień teorii i filozofii prawa. Konstytucja, red. A. Bator, Wrocław 1999, s. 116.

28 P. Tuleja, Stosowanie Konstytucji RP w świetle zasady jej nadrzędności (wybrane problemy), Kraków 2003, s. 321-329.

29 K. Działocha, Zasada bezpośredniego stosowania Konstytucji RP, [w:] Podstawowe problemy stosowania Konstytucji RP, red. A. Preisner, T. Zalasiński, Wrocław 2005, s. 85 i n.

$30 \quad$ K. Działocha, Bezpośrednie stosowanie..., s. 20.

31 A. Bator, A. Kozak, Wykładnia prawa w zgodzie z Konstytucja, [w:] Polska kultura prawna a proces integracji europejskiej, red. S. Wronkowska, Kraków 2005, s. 45.

32 P. Tuleja, Normatywna treść praw jednostki w ustawach Konstytucyjnych RP, Warszawa 1997, s. 138, 147. 
nej stanowi dostateczne uzasadnienie dla aktywności sędziego wykraczającej poza proste stosowanie ustaw ${ }^{33}$. Niemniej jednak w omawianym przypadku nie jest uprawione twierdzenie jakoby NSA dokonywał jedynie wykładni treści ustawy procesowej w zgodzie z dyrektywami płynącymi z konstytucji. Rozumowanie sądu nie ogranicza się bowiem do wyjaśnienia treści klauzuli odsyłającej zawartej w art. $58 \$ 1$ pkt 6 p.s.a. Przytoczony przepis obok opisu skutków prawnych pewnych zdarzeń procesowych realizuje funkcję informacyjną. Wskazuje, bowiem, że poza treścią art. $58 \$ 1$ p.s.a. znajdują się inne wprost bądź pośrednio wynikające z przepisów prawa procesowego podstawy odrzucenia skargi. Trudno uznać jakoby prokonstytucyjna wykładnia sformułowania „innych przyczyn” miała per se implikować w płaszczyźnie procesowej niedopuszczalność drogi sądowej. Bezpośrednie stosowanie konstytucji w omawianym przypadku sprowadza się do wykreowania owej „innej przyczyny”. Nie ogranicza się tym samym do właściwego ustalenia treści art. 58 $\$ 1$ pkt 6 p.s.a. Przeto okolicznością konstruującą wykładniczą formułę współstosowania konstytucji jest interpretacja podlegających różnej wykładni przepisów ustaw jednocześnie z przepisem konstytucji w rezultacie czego organ stosujący prawo buduję normę prawną ${ }^{34}$. Jak się wydaje w omawianym przypadku brak jest drugiego z elementów koniecznych, a mianowicie podlegającego wykładni przepisu ustawy.

Tym samym uzasadnienie komentowanego postanowienia zawiera wewnętrzną sprzeczność. Z jednej strony wskazuje się, że przepisy konstytucji mogą stanowić „inną przyczynę”, o której mowa w art. $58 \$ 1$ pkt 6 p.s.a., co sugerowałoby intencję samoistnego zastosowania ustawy zasadniczej w zakresie niezbędnym do ustalenia przyczyny odrzucenia skargi. Z drugiej strony NSA podkreśla, iż „stosowanie przepisów Konstytucji może i powinno zasadniczo polegać na ich współstosowaniu z przepisami ustawowymi”. Ponad wszelką wątpliwość nawet rozszerzająca wykładnia treści art. $58 \S 1$ pkt 6 p.s.a. nie może uzasadniać rezultatu zaproponowanego w treści pytania prawnego. Stąd też przyjmujemy, że omawiany przypadek stanowi de facto nieuzasadnioną próbę samoistnego zastosowania konstytucji przez NSA.

33 D. Dąbek, Prawo sędziowskie w polskim prawie administracyjnym, Warszawa 2010, s. 262-267.

34 L. Garlicki, Bezpośrednie stosowanie..., s. 16. 


\section{IV.}

W ramach właściwego podsumowania należy pochylić się nad systemowymi konsekwencjami proponowanej przez NSA konstrukcji procesowej. Przy uwzględnieniu wynikającego z przepisów konstytucji domniemania prawa do sądu ${ }^{35}$, jako niedopuszczalne wydają się być wszelkie próby kreowania pozaustawowych przesłanek dopuszczalności drogi sądowej. Zauważmy, że NSA z odwołaniem się do treści ustawy zasadniczej kreuje istotny regulator dostępu do sądu w postaci obowiązku każdoczesnej oceny doniosłości sprawy ${ }^{36}$. Uzasadnione wydaje się twierdzenie, że na zasadzie art. $58 \$ 1$ pkt 6 p.s.a. w zw. z art. 8 , art. 2 oraz art. 45 ust. 1 Konstytucji RP doszłoby do inkorporowania do p.s.a. instytucji quasi przedsądu. Poczyniona w tym miejscu analogia jedynie z pozoru wydaje się być odległa. Analiza normatywnej treści instytucji procesowej przedsądu uzasadnia twierdzenie, że proponowana przez NSA konstrukcja jest doń zbliżona. Znaczenie przedsądu w postępowaniu wyczerpuje się w możliwości limitowania dostępu do sądu $\mathrm{z}$ odwołaniem się do konstrukcji nadużycia prawa do skargi ${ }^{37}$. Przy czym ocena doniosłości sprawy, a co za tym idzie celowości udzielania ochrony prawnej skarżącemu pozostawiona jest ocenie sądu. Konstrukcja proponowana przez NSA w postanowieniu z 16 października 2015 r. wprowadza tożsamy mechanizm. Skoro tak to sąd w nieakceptowalny sposób wkroczył w sferę wyłącznej właściwości ustawodawcy, bowiem tylko w drodze ustawy mogą być limitowane prawa i wolności jednostki w Rzeczpospolitej Polskiej. Przywołana okoliczność stanowi przesłankę formalną zastosowania art. 31 ust. 3 Konstytucji RP ${ }^{38}$. NSA nie uwzględnił również formułowanego $\mathrm{w}$ piśmiennictwie postulatu powściągliwości w wykładni przepisów w zgodzie z konstytucją. Owa dyrektywa postępo-

35 Z. Czeszejko-Sochacki, Prawo do sadu w świetle Konstytucji Rzeczypospolitej Polskiej (Ogólna charakterystyka), „Państwo i Prawo” 1997, z. 11-12, s. 95.

36 Pomijamy w tym miejscu okoliczność jaką jest określenie przesłanek zastosowania rygoru procesowego w postaci odrzucenia skargi przy pomocy pojęć nieostrych nadto rozszerzających dyskrecjonalną władzę sędziego.

37 R. Hauser, Wstępne założenia nowelizacji ustawy - Prawo o postępowaniu przed sądami administracyjnymi, „Państwo i Prawo” 2013, z. 2, s. 25, 27.

38 L. Garlicki, Komentarz do art. 31, [w:] Konstytucja Rzeczypospolitej Polskiej..., s. 19-21. 
wania ma zapobiegać sytuacjom, w których sąd w istocie zastępuje prawodawcę przełamując zasadę podziału władz ${ }^{39}$.

Mając na uwadze zasygnalizowane powyżej wątpliwości należy wskazać, iż zawarta $\mathrm{w}$ treści pytania prawnego propozycja wykładni przepisów jest nie do zaakceptowania. Oceny tej nie zmienia fakt, iż NSA w sposób prawidłowy zidentyfikował podstawowe problemy sądownictwa administracyjnego oraz zasadnicze przyczyny globalnej przewlekłości postępowań. Niemniej jednak to rolą ustawodawcy jest rozważanie celowości wprowadzenia dodatkowych przesłanek ograniczających dostęp do sądownictwa administracyjnego. Co więcej jak się wydaje bez zmiany treści art. 184 Konstytucji RP dalsze ograniczanie dostępności postępowania sądowoadministracyjnego w kształcie proponowanym przez NSA nie może mieć miejsca ${ }^{40}$.

Niestety zagadnienie prawne przedstawione składowi siedmiu sędziów pozostanie na chwilę obecną nierozstrzygnięte. NSA w postanowieniu z 21 marca $2016 \mathrm{r}^{41}$ odmówił podjęcia uchwały. Uzasadnieniem dla owego rozstrzygnięcia było uprzednie pozytywne ustalenie przez NSA istnienia drogi sądowej ${ }^{42} \mathrm{w}$ sprawie stanowiącej przyczynek dla sformułowania pytania prawnego. W rezultacie czego dyskusja nad dopuszczalnym zakresem kreowania negatywnych przesłanek procesowych $\mathrm{z}$ odwołaniem się do treści Konstytucji RP pozostaje otwarta i nader aktualna.

39 P. Tuleja, Stosowanie Konstytucji..., s. 340.

40 R. Hauser, J. Drachal, E. Mzyk, Dwuinstancyjne sq̨downictwo administracyjne. Omówienie podstawowych zasada i instytucji procesowych, Warszawa-Zielona Góra 2003, s. 77-78.

41 I OPS 3/15.

42 Postanowienie NSA z 1 października 2013 r., I OSK 2139/13. 